Jurnal Keperawatan Silampari

Volume 5, Nomor 1, Desember 2021

e-ISSN: 2581-1975

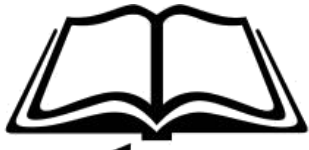

p-ISSN: $2597-7482$

DOI: https://doi.org/10.31539/jks.v5i1.2367

\title{
PENURUNAN KADAR GULA DARAH PASIEN DM TIPE 2 DENGAN AKTIVITAS FISIK
}

\author{
I Made Sundayana ${ }^{1}$, I Dewa Ayu Rismayanti ${ }^{2}$, Ida Ayu Putu Desta Candra Devi ${ }^{3}$ \\ Sekolah Tinggi Ilmu Kesehatan Buleleng ${ }^{1,2,3}$ \\ i.dewa.ayu.rismayanti-2019@fkp.unair.ac.id ${ }^{2}$
}

\begin{abstract}
ABSTRAK
Penelitian ini bertujuan untuk mengetahui hubungan antara aktivitas fisik dengan kadar glukosa darah pada pasien DM tipe 2. Desain penelitian yang digunakan adalah deskriptif korelasional dengan pendekatan cross-sectional. Hasil analisis univariat menunjukkan bahwa mayoritas responden memiliki aktivitas sedang yaitu sebanyak 19 orang $(43,2 \%)$ dan mayoritas responden memiliki kadar gula darah buruk yaitu 21 orang (47,7\%). Hasil analisis bivariat menunjukkan bahwa $\mathrm{p}$ value $=0,000<0,05$ dengan nilai koefisien korelasi $(\mathrm{r}=0,756)$. Simpulan, ada hubungan aktivitas fisik dengan kadar gula darah pada pasien DM Tipe 2.
\end{abstract}

Kata Kunci: Aktivitas Fisik, Diabetes Mellitus Tipe 2, Glukosa Darah

\section{ABSTRACT}

This study aims to determine the relationship between physical activity and blood glucose levels in patients with type 2 diabetes. The research design used was a descriptive correlation with a cross-sectional approach. The results of the univariate analysis showed that the majority of respondents had moderate activity, as many as 19 people (43.2\%), and the majority of respondents had poor blood sugar levels, namely 21 people (47.7\%). The results of the bivariate analysis showed that $p$-value $=0.000<0.05$ with a correlation coefficient $(r=0.756)$. In conclusion, there is a relationship between physical activity and blood sugar levels in Type 2 DM patients.

Keywords: Physical Activity, Type 2 Diabetes Mellitus, Blood Glucose

\section{PENDAHULUAN}

Diabetes adalah penyakit metabolik yang ditandai dengan meningkatnya kadar glukosa dalam tubuh (hiperglikemia) yang disebabkan oleh terganggunya sistem sekresi insulin (Soelistijo et al., 2019). Diabetes merupakan suatu penyakit kronis yang terjadi karena pankreas tidak bisa menghasilkan cukup insulin (hormon yang mengatur gula darah atau glukosa), atau ketika tubuh tidak bisa secara efektif menggunakan insulin yang dihasilkannya. Diabetes adalah suatu masalah kesehatan masyarakat yang sangat penting dan menjadi salah satu penyakit tidak menular yang menjadi prioritas dan target tindak lanjut dari pemimpin dunia (Kemenkes RI, 2019). 
Manajemen diri merupakan hal yang penting dilakukan untuk dapat menurunkan kadar gula darah pada pasien DM tipe 2. Berdasarkan International Diabetes Federation (IDF), manajemen diri pada pasien DM terdiri dari 4 pilar utama yaitu yaitu pengelolaan diet sehat, aktivitas fisik, manajemen gula darah dan perawatan kaki (Beck et al., 2018), namun penelitian yang banyak dilakukan hanya berfokus pada manajemen diet saja, sedangkan aspek manajemen diri yang lain, khususnya aktivitas fisik masih belum banyak dilakukan. Diabetes Mellitus menjadi isu penting di Indonesia, karena merupakan salah satu Penyakit Tidak Menular (PTM) dengan angka kematian yang cukup tinggi.

Menurut data IDF (2019) ada 463 juta orang dewasa (usia 20-79 tahun) yang mengalami DM di dunia pada tahun 2019 dan pada tahun 2045 angkanya diperkirakan akan meningkat menjadi 700 juta (IDF, 2019; Setyawati et al., 2020). Insiden DM di Indonesia meningkat dari tahun 2013 sebesar 6,9\% menjadi 10,9\% pada tahun 2018 (Kementrian Kesehatan Republik Indonesia, 2018), selain itu, prevalensi DM di Provinsi Bali juga mengalami peningkatan menjadi 1,7\% pada tahun 2018 dari angka 1,3\% pada tahun 2013 (Kemenkes, 2018).

Aktivitas fisik merupakan salah satu strategi manajemen pertama yang disarankan untuk pasien DM tipe 2. Aktivitas fisik secara positif dapat mempengaruhi kebugaran tubuh, pembentukan berat badan yang ideal dan sensitivitas insulin. Pelaksanaan aktivitas fisik yang benar selanjutnya akan membantu mengontrol kadar gula darah (Kirwan et al., 2017; Chiang et al., 2019). Aktivitas fisik harus dilakukan secara teratur setiap hari dengan ritme yang ringan dan tidak terlalu melelahkan bagi pasien DM (Kirwan et al., 2017). Penelitian yang dilakukan oleh Putri (2016) aktivitas fisik ringan berupa jalan kaki, bersepeda, senam serta joging dapat membantu mengontrol kadar gula darah dengan baik, dengan memperhatikan durasi dan intensitas latihan yaitu dilaksanakan selama 30 menit serta sebanyak 3 kali dalam satu minggu.

Faktor yang sangat mempengaruhi kadar gula darah pada pasien DM adalah aktivitas fisik yang dilakukan. Terjadinya kadar gula darah yang tidak terkontrol kebanyakan terjadi karena aktivitas yang kurang dilakukan oleh penderita diabetes melitus. Kadar gula darah normal sewaktu $\leq 140 \mathrm{mg} / \mathrm{dL}$ sesudah 2 jam makan sedangkan $\leq 100 \mathrm{mg} / \mathrm{dL}$ gula darah puasa. Sedangkan untuk pasien yang sudah terdiagnosa DM kadar glukosanya $\geq 200 \mathrm{mg} / \mathrm{dL}$ (Widana, 2019). Aktivitas fisik merupakan gerakan-gerakan yang dilakukan oleh otot pada tubuh dalam penyakit diabetes melitus. Pada penderita DM aktivitas fisik memiliki peranan yang sangat penting dalam mengendalikan kadar gula darah dalam tubuh, dimana saat melakukan latihan fisik terjadi peningkatan pemakaian glukosa oleh otot yang aktif sehingga secara langsung dapat menyebabkan penurunan jumlah kadar gula darah dalam tubuh. Selain aktivitas fisik dapat menurunkan kadar gula darah dalam tubuh aktivitas fisik juga dapat menurunkan berat badan, meningkatkan fungsi kardiovaskuler dan respirasi (Alza et al., 2020).

Aktivitas fisik dapat menurunkan risiko terjadinya DM melalui efek berat badan dan sensitivitas insulin. Seseorang dengan kadar lemak yang rendah memiliki risiko yang lebih rendah juga untuk menderita diabetes. Selain itu kurangnya aktivitas fisik juga membuat sistem sekresi dalam tubuh berjalan lambat. Akibatnya terjadilah penumpukan lemak di dalam tubuh yang akan terus bertambah yang akan mengakibatkan berat badan berlebih dan mengarah ke timbulnya diabetes mellitus (Hariawan et al., 2019). 
Aktivitas fisik juga direkomendasikan oleh Kementerian Kesehatan Indonesia dalam aksi CERDIK yang merupakan sebuah kampanye kesehatan untuk mencegah terjadinya penyakit tidak menular salah satunya adalah diabetes mellitus. Aksi CERDIK PTM terdiri dari cek kesehatan, enyahkan rokok, rajin aktivitas fisik, diet sehat, istirahat yang cukup dan kelola stres (Kemenkes, 2017). Penelitian ini berfokus pada hubungan antara aktivitas fisik dengan kadar gula darah pada pasien DM tipe 2.

\section{METODE PENELITIAN}

Metode penelitian yang digunakan adalah penelitian kuantitatif. Desain dari penelitian ini adalah deskriptif korelasional dengan menggunakan pendekatan cross-sectional yaitu pendekatan penelitian yang dilakukan hanya dalam satu waktu saja dan tidak ada tindak lanjut. Penelitian ini dilalukan di Puskesmas Kubutambahan 1, Desa Kubutambahan, Kecamatan Kubutambahan, Kabupaten Buleleng pada bulan Februari-Maret 2021. Teknik perhitungan besar sampel menggunakan rumus slovin, dan diperoleh besar sampel dalam penelitian ini adalah 44 pasien DM tipe 2. Kriteria inklusi yang ditetapkan dalam penelitian ini adalah responden merupakan pasien DM tipe 2, telah menderita penyakit DM selama 13 tahun terakhir, dan rutin melakukan pemeriksaan di puskesmas.

Pengambilan sampel menggunakan metode non-probability sampling yaitu purposive sampling yaitu teknik penetapan sampel dengan cara memilih sampel diantara populasi sesuai dengan yang dikehendaki oleh peneliti. Instrumen penelitian yang digunakan berupa kuesioner yaitu Global Physical Activity Questionnaire (GPAQ) dan telah memenuhi syarat validitas serta reliabilitas. Selain itu, penelitian ini juga memperhatikan prinsip-prinsip etik seperti penggunaan lembar persetujuan menjadi responden (informed consent), prinsip manfaat (beneficience), kerahasiaan (confidentiality), dan keadilan (justice).

Penelitian dimulai dengan melakukan perizinan dengan pihak terkait, dan kemudian dilakukan pengumpulan data menggunakan kuesioner, peneliti juga mengumpulkan data demografi responden seperti jenis kelamin, usia, tingkat pendidikan dan pekerjaan. Data yang dikumpulan selanjutnya dilakukan analisis univariat berupa analisis deskriptif dan analisis bivariat menggunakan uji korelasi spearman rank dengan nilai signifikansi $\mathrm{p}<0,05$.

\section{HASIL PENELITIAN}

Tabel. 1

Data Demografi Responden Penelitian

\begin{tabular}{|c|c|c|c|}
\hline $\begin{array}{l}\text { Karakteristik Demografi } \\
\text { Responden }\end{array}$ & Kategori & Frekuensi (f) & Persentase (\%) \\
\hline \multirow[t]{3}{*}{ Jenis Kelamin } & Laki-Laki & 19 & 43,2 \\
\hline & Perempuan & 25 & 56,8 \\
\hline & Total & 44 & 100,0 \\
\hline \multirow[t]{3}{*}{ Tingkat Pendidikan } & SD & 20 & 45,5 \\
\hline & SMP & 24 & 54,5 \\
\hline & Total & 44 & 100,0 \\
\hline \multirow[t]{4}{*}{ Pekerjaan } & Tidak Bekerja & 15 & 34,1 \\
\hline & Wiraswasta & 13 & 29,5 \\
\hline & Petani/Nelayan/Buruh & 16 & 36,4 \\
\hline & Total & 44 & 100,0 \\
\hline
\end{tabular}


Berdasarkan tabel 1 menunjukkan bahwa mayoritas responden penelitian berjenis kelamin perempuan sebanyak 25 orang $(56,8 \%)$. Berdasarkan riwayat pendidikan diketahui paling banyak responden memiliki riwayat pendidikan SMP yaitu 24 orang $(54,5 \%)$. Sedangkan berdasarkan jenis pekerjaan yang dilakukan, sebanyak 16 responden bekerja sebagai petani/nelayan/buruh $(36,4 \%)$.

Tabel. 2

Data Demografi Usia

Responden Penelitian

\begin{tabular}{lccccc}
\hline $\begin{array}{c}\text { Karakteristik Demografi } \\
\text { Responden }\end{array}$ & N & Mean & Min. & Max. & SD \\
\hline Usia & 44 & 65,95 & 53 & 88 & 6,423 \\
\hline
\end{tabular}

Berdasarkan tabel 2 menunjukkan bahwa usia termuda dari responden penelitian adalah 53 tahun, dan usia paling tua adalah 88 tahun dengan nilai standar deviasi $(\mathrm{SD}=$ $6,423)$.

Tabel. 3

Distribusi Variabel Penelitian

\begin{tabular}{clcc}
\hline Variabel & \multicolumn{1}{c}{ Kategori } & Frekuensi (f) & Persentase (\%) \\
\hline Aktivitas Fisik & Tinggi & 9 & 20,5 \\
& Sedang & 19 & 43,2 \\
& Rendah & 16 & 36,4 \\
\cline { 2 - 4 } & Total & 44 & 100,0 \\
\hline \multirow{2}{*}{ Kadar Gula Darah } & Baik & 6 & 13,6 \\
& Sedang & 17 & 38,6 \\
& Buruk & 21 & 47,7 \\
\cline { 2 - 4 } & Total & 44 & 100,0 \\
\hline
\end{tabular}

Berdasarkan tabel 3 mayoritas responden memiliki aktivitas sedang yaitu sebanyak 19 orang (43,2\%). Berdasarkan pengukuran kadar gula darah, diketahui mayoritas responden memiliki kadar gula darah buruk yaitu 21 orang $(47,7 \%)$.

Tabel. 4

Hasil Uji Korelasi Spearman rank

\begin{tabular}{ccc}
\hline DM & Aktivitas Fisik & Kadar Gula Darah \\
\hline Coefficien Correlations & 0,756 & 0,756 \\
P. Value & 0,000 & 0,000 \\
\hline
\end{tabular}

Berdasarkan tabel 4 menunjukkan hasil uji korelasi spearman rank antara variabel aktivitas fisik dan kadar gula darah. Berdasarkan analisis diketahui terdapat hubungan yang signifikan antara aktivitas fisik dengan kadar gula darah $(\mathrm{p}=0,000)$ dengan kekuatan hubungan antar variabel adalah hubungan kuat dan positif, yang dibuktikan dengan nilai koefisien korelasi $(\mathrm{r}=0,756)$. 


\section{PEMBAHASAN}

Hasil penelitian menunjukkan, mayoritas responden yang menderita DM tipe 2 adalah perempuan. Kasus DM lebih banyak terjadi pada perempuan, hal tersebut dikarenakan secara fisik wanita memiliki peluang peningkatan indeks masa tubuh yang lebih besar. Tetapi, kategori jenis kelamin tidak berpengaruh terhadap kenaikan atau penurunan kadar gula darah pada penderita diabetes melitus karena laki-laki maupun perempuan memiliki risiko yang sama besar untuk mengalami penyakit DM (Riskesdas, 2018). Jenis kelamin juga menjadi salah satu faktor yang dapat mempengaruhi aktivitas fisik seseorang. Aktivitas fisik pada remaja laki-laki hampir sama dengan remaja perempuan, namun setelah pubertas remaja laki-laki biasanya mempunyai intensitas dalam aktivitas fisik yang jauh lebih besar (Widana, 2019).

Karakteristik yang lainnya adalah tingkat pendidikan. Diketahui mayoritas responden memiliki tingkat Pendidikan Menengah Pertama (SMP). Tingkat pendidikan memiliki pengaruh terhadap meningkatnya kadar gula darah. Orang yang memiliki tingkat pendidikan yang tinggi biasanya akan memiliki banyak pengetahuan tentang kesehatan. Dengan adanya pengetahuan yang tinggi maka orang tersebut akan lebih memahami tentang penyakitnya dan mengetahui lebih banyak informasi mengenai penyakitnya, selain itu ia akan memiliki kesadaran dalam menjaga kesehatannya dan memiliki pola hidup yang lebih baik.

Berdasarkan karakteristik usia, diketahui rata-rata usia responden memasuki kategori usia lansia awal, dimana usia tersebut sangat mempengaruhi kenaikan kadar gula darah. Hal ini dikarenakan pada rentang usia terjadi peningkatan gula darah disebabkan oleh fungsi sel pankreas dan insulin berkurang, perubahan karena usia itu sendiri yang berkaitan dengan resistensi insulin akibat kurangnya massa otot dan perubahan vaskuler dan kurangnya aktivitas fisik. Komponen tubuh yang dapat mengalami perubahan adalah sel beta pankreas yang menghasilkan hormon insulin, sel-sel jaringan target glukosa, sistem saraf, dan hormon lain yang mempengaruhi kadar gula darah (Soelistijo et al., 2019; Ang, 2020).

Setiap orang pasti mengalami proses degereratif oleh karena faktor bertambahnya usia. Proses degeneratif yang terjadi diantaranya adalah penyusutan otot, penyusutan lemak sub kutan, dan melambatnya kinerja organ-organ tubuh. Usia berpengaruh terhadap peningkatan risiko DM, semakin tua usia seseorang akan berdampak pada penurunan fleksibelitas dan kekuatan organ serta fungsinya dalam tubuh (Yosmar et al., 2018). Selain itu, aktivitas fisik akan meningkat mencapai maksimal pada remaja sampai usia 25-30 tahun, kemudian akan terjadi penurunan kapasitas fungsional dari seluruh tubuh. Semakin bertambahnya usia maka aktivitas fisik yang dilakukan akan semakin sedikit atau berkurang dikarenakan lebih cepat merasakan lelah pada saat beraktivitas, oleh karena itu, usia sangatlah berpengaruh terhadap jenis aktivitas yang dapat dilakukan.

Hasil penelitian menunjukkan bahwa terdapat hubungan antara aktivitas fisik dengan penurunan kadar gula darah. Aktivitas fisik adalah setiap gerakan tubuh yang dapat meningkatkan pengeluaran energi. Aktivitas fisik dapat membantu penderita DM dalam meningkatkan kebugaran, kekuatan, peningkatan kontrol glikemik, penurunan resistensi insulin, pemeliharaan penurunan berat badan, dan pengurangan tekanan darah. Ketika seseorang melakukan aktivitas fisik akan terjadinya peningkatan aliran darah yang dapat menyebabkan jala-jala kapiler terbuka sehingga lebih banyak tersedia reseptor insulin dan reseptor menjadi lebih aktif (Wanjaya et al., 2020). 
Diabetes melitus (DM) didefinisikan sebagai suatu penyakit atau gangguan metabolisme kronis dengan multietiologi yang ditandai dengan tingginya kadar gula darah disertai dengan gangguan metabolisme karbohidrat, lipid dan protein sebagai akibat insufisiensi fungsi insulin (Kretchy et al., 2020). Insufisiensi insulin dapat disebabkan oleh gangguan atau defesiensi produksi insulin oleh sel-sel beta Langerhans kelenjar pankreas, atau disebabkan oleh kurang responsifnya sel-sel tubuh terhadap insulin (Yosmar et al., 2018).

Salah satu dari 4 pilar manajemen DM adalah aktivitas fisik. Dalam hal ini, perawat sebagai seorang edukator dan konselor bagi pasien dapat memberikan bantuan kepada pasien dalam bentuk supportive educative system dengan memberikan pendidikan kesehatan yang bertujuan untuk memandirikan pasien dalam melakukan manajemen diri khususnya dalam melakukan aktivitas fisik. Pelaksanaan aktivitas atau latihan jasmani yang dilakukan penderita DM selama 5-30 menit dalam sehari dapat menurunkan kadar gula dalam darah, timbunan lemak, dan tekanan darah (Mamo et al., 2019).

Hal tersebut dikarenakanketika aktivitas tubuh tinggi penggunaan glukosa dalam tubuh oleh otot ikut meningkat, sehingga sintesis glukosa endogen akan ditingkatkan agar kadar gula dalam darah tetap seimbang, sehingga tubuh akan mengkompensasi kebutuhan glukosa yang tinggi (Widana, 2019). Aktivitas fisik akan sangat mempengaruhi kadar gula darah pada penderita DM, dikarenakan pada saat seseorang melakukan aktivitas fisik akan terjadi peningkatan pemakaian glukosa oleh otot yang aktif sehingga secara langsung dapat menyebabkan penurunan jumlah kadar gula darah dalam tubuh, semakin rutin seseorang melakukan aktivitas fisik maka kadar gula darah pada seseorang juga akan lebih terkontrol (Hariawan et al., 2019; Wanjaya et al., 2020).

\section{SIMPULAN}

Rata-rata usia responden adalah 65,95 tahun, jenis kelamin sebagian besar berjenis kelamin perempuan. Rata-rata sebagian responden yang memiliki aktivitas fisik sedang dan distribusi kadar gula darah sebagian besar responden memiliki kadar gula darah buruk. Ada hubungan aktivitas fisik dengan kadar gula darah pada pasien DM tipe 2.

\section{SARAN}

\section{Bagi Institusi Pendidikan}

Diharapkan dapat menjadi suatu panduan bagi institusi dalam meningkatkan kualitas pembelajaran dibidang keperawatan khususnya mengenai hubungan aktivitas fisik dengan kadar gula darah pada pasien DM tipe 2.

\section{Bagi Tempat Penelitian}

Diharapkan bisa menjadi acuan dasar keperawatan dalam pemberian edukasi mengenai aktivitas fisik dan kadar gula darah kepada masyarakat di wilayah kerja Puskesmas Kubutambahan 1.

\section{Bagi Peneliti Selanjutnya}

Diharapkan bisa menjadi suatu bahan dan acuan untuk peneliti selanjutnya dalam melakukan penelitian yang sejenis yang berkaitan dengan hubungan aktivitas fisik dengan kadar gula darah pada pasien DM tipe 2 sehingga dapat menjadi acuan untuk melakukan penelitian selanjutnya. 


\section{DAFTAR PUSTAKA}

Alza, Y., Arsil, Y., Marlina, Y., Novita, L., \& Agustin, N. D. (2020). Aktivitas Fisik, Durasi Penyakit dan Kadar Gula Darah pada Penderita Diabetes Mellitus (DM) Tipe 2. Jurnal GIZIDO, 12(1), 18-26. https://doi.org/10.47718/gizi.v12i1.907

Ang, G. Y. (2020). Age Of Onset Of Diabetes And All-Cause Mortality. World Journal of Diabetes, 11(4), 95-99. DOI: 10.4239/wjd.v11.i4.95

Beck, J., Greenwood, D. A., Blanton, L., Bollinger, S. T., Butcher, M. K., Condon, J. E., Cypress, M., Faulkner, P., Fischl, A. H., Francis, T., Kolb, L. E., Lavin-Tompkins, J. M., MacLeod, J., Maryniuk, M., Mensing, C., Orzeck, E. A., Pope, D. D., Pulizzi, J. L., Reed, A. A., \& Wang, J. (2018). 2017 National Standards for Diabetes SelfManagement Education and Support. Diabetes Educator, 44(1), 35-50. https://doi.org/10.1177/0145721718754797

Chiang, S. L., Heitkemper, M. M. L., Hung, Y. J., Tzeng, W. C., Lee, M. S., \& Lin, C. H. (2019). Effects Of A 12-Week Moderate-Intensity Exercise Training on Blood Glucose Response in Patients With Type 2 Diabetes: A Prospective Longitudinal Study. Medicine (United States), 98(36). https://doi.org/10.1097/MD.0000000000016860

Hariawan, H., Fathoni, A., \& Purnamawati, D. (2019). Hubungan Gaya Hidup (Pola Makan dan Aktivitas Fisik) dengan Kejadian Diabetes Melitus di Rumah Sakit Umum Provinsi NTB. Jurnal Keperawatan Terpadu (Integrated Nursing Journal), 1(1), 1. DOI: $10.32807 / j k t . v 1 i 1.16$

IDF. (2019). IDF Diabetes Atlas 9th edition 2019. In International Diabetes Federation Diabetes Atlas, Ninth Edition. https://www.diabetesatlas.org/en/

Kemenkes, R. I. (2017). Rencana Aksi Nasional Penyakit Tidak Menular 2015-2019. 3540, 76-112. http://www.p2ptm.kemkes.go.id/dokumen-ptm/buku-rencana-aksinasional-2015-2019

Kemenkes, R. I. (2018). Profil Kesehatan Indonesia Tahun 2018. Jakarta: Kementerian Kesehatan RI, pp. 170-173. https://pusdatin.kemkes.go.id/resources/download/pusdatin/profil-kesehatanindonesia/PROFIL_KESEHATAN_2018_1.pdf

Kemenkes, R.I. (2019). Hari Diabetes Sedunia Tahun 2018. Pusat Data dan Informasi Kementrian Kesehatan RI, pp. 1-8. https://pusdatin.kemkes.go.id/article/view/19041500002/hari-diabetes-sedunia2018.html

Kirwan, J. P., Sacks, J., \& Nieuwoudt, S. (2017). The Essential Role of Exercise in the Management of Type 2 Diabetes. Cleveland Clinic journal of medicine, 84(7 Sipplement 1), 15-21. DOI: 10.1016/j.gde.2016.03.011

Kretchy, I. A., Koduah, A., Ohene-Agyei, T., Boima, V., \& Appiah, B. (2020). The Association between Diabetes-Related Distress and Medication Adherence in Adult Patients with Type 2 Diabetes Mellitus: A Cross-Sectional Study. Journal of Diabetes Research, 2020. https://doi.org/10.1155/2020/4760624

Mamo, Y., Bekele, F., Nigussie, T., \& Zewudie, A. (2019). Determinants Of Poor Glycemic Control Among Adult Patients With Type 2 Diabetes Mellitus In Jimma University Medical Center, Jimma Zone, South West Ethiopia: A Case Control Study. BMC Endocrine Disorders, 19(1). https://doi.org/10.1186/s12902-019-0421-0 
Putri, E. L. (2016). Hubungan antara Latihan Jasmani dengan Kadar Glukosa Darah Penderita Diabetes. Jurnal Berkala Epidemiologi, 4(7), 188-199. DOI: 10.20473/jbe.v4i2.2016.188

Riskesdas. (2018). Hasil Utama Riset Kesehata Dasar (Riskesdas). Journal of Physics A: Mathematical and Theoretical, 44(8), 1-200. doi: 10.1088/1751-8113/44/8/085201

Setyawati, A. D., Ngo, T. H. L., Padila, P., \& Andri, J. (2020). Obesity and Heredity for Diabetes Mellitus among Elderly. JOSING: Journal of Nursing and Health, 1(1), 2631. https://doi.org/https://doi.org/https://doi.org/10.31539/josing.v1i1.1149

Soelistijo, S. A., Lindarto, D., Decroli, E., Permana, H., Sucipto, K. W., Kusnadi, Y., Budiman, B., Ikhsan, R., Sasiarini, L., \& Sanusi, H. (2019) Pedoman pengelolaan dan pencegahan diabetes melitus tipe 2 dewasa di Indonesia 2019. Perkumpulan Endokrinologi Indonesia, pp. 1-117. https://pbperkeni.or.id/wpcontent/uploads/2020/07/Pedoman-Pengelolaan-DM-Tipe-2-Dewasa-di-IndonesiaeBook-Pdf-1.pdf

Wanjaya, I. K. O., Yasa, I. P., Rahayu, V. M., Endang, S. P., \& Rasdini, I. A. (2020). Aktivitas Fisik dengan Diabetik Neuropati Perifer pada Pasien DM Tipe 2. Jurnal Gema Keperawatan, 13(Juni), 1-9. https://ejournal.poltekkesdenpasar.ac.id/index.php/JGK/article/view/1173

Widana, K. (2019). Hubungan antara Aktivitas Fisik dengan Kadar Gula Darah Sewaktu pada Penderita Diabetes Melitus Tipe 2 di RSUD Sleman Yogyakarta. Kazoku Syakaigaku Kenkyu, 28(2), 250-250. DOI: 10.4234/jjoffamilysociology.28.250

Yosmar, R., Almasdy, D., \& Rahma, F. (2018). Survei Risiko Penyakit Diabetes Melitus terhadap Masyarakat Kota Padang. Jurnal Sains Farmasi dan Klinis, 5(2), 134-141. DOI: $10.25077 /$ jsfk.5.2.134-141.2018 